Jurnal Penelitian dan Evaluasi Pendidikan

\title{
EVALUASI PROGRAM PEMBELAJARAN ILMU PENGETAHUAN SOSIAL SMP/MTS DI KOTA BIMA
}

\author{
Ida Waluyati \\ Sekolah Tinggi Ilmu Tarbiyah (STIT) Sunan Giri Bima NTB \\ ida.waluyati@yahoo.com
}

\begin{abstract}
Abstrak
Penelitian ini bertujuan untuk mengetahui kesesuaian pelaksanaan program pembelajaran IPS SMP/MTs di Kota Bima, yang meliputi: 1) perencanaan, 2) pelaksanaan, dan 3) penilaian serta tindak lanjutnya, 4) dan hasil pembelajaran kognitif IPS siswa dengan standar Kriteria Ketuntasan Minimal belajar. Penelitian ini merupakan penelitian evaluasi dengan menggunakan Model Countenance Stake, yang meliputi evaluasi Antecedents, Transactions, dan Outcomes. Subjek penelitian adalah 78 guru IPS yang diambil secara populasi dan siswa sejumlah 390 orang yang dipilih secara Quota Stratified Random Sampling. Teknik pengumpulan data yang digunakan adalah angket, tes, dan dokumentasi. Instrumen yang digunakan adalah kuesioner, tes, dan daftar cek. Analisis data dilakukan dengan analisis deskriptif kuantitatif, dengan membandingkan hasil penelitian dengan kriteria yang telah ditentukan. Hasil penelitian menunjukkan bahwa kesesuaian antara pelaksanaan program pembelajaran IPS SMP/MTs di Kota Bima dengan standar proses pendidikan adalah sebagai berikut.(1) Perencanaan pembelajaran berada pada kategori baik (sesuai), (2) Proses pembelajaran berada pada kategori cukup baik (cukup sesuai), (3) Penilaian hasil belajar serta tindak lanjut hasil penilaian berada pada kategori baik (sesuai), (4) dan hasil belajar kognitif IPS siswa berada pada kategori baik (sesuai) standar Kriteria Ketuntasan Minimal belajar.
\end{abstract}

Kata kunci: evaluasi program, pembelajaran IPS 
EVALUATION OF SOCIAL STUDIES INSTRUCTIONAL PROGRAM FOR JUNIOR HIGH SCHOOL/MADRASAH TSANAWIYAH IN BIMA REGENCY

\author{
Ida Waluyati \\ Sekolah Tinggi Ilmu Tarbiyah (STIT) Sunan Giri Bima NTB \\ ida.waluyati@yahoo.com
}

\begin{abstract}
This study aims to evaluate the implementation of social studies instructional program for Junior High School/Madrasah Tsanawiyah in Bima regency, which involves: (1) planning, (2) implementation process, (3) learning outcome assessments and its follow-up with education process standard, (4) and students cognitive learning outcomes with learning minimal criteria standard. This is an evaluation research study employing the Countenance Stake's model consisting of the evaluation of antecedents, transactions, and outcomes. The subjects of this study were 78 social studies teachers of Junior High School/Madrasah Tsanawiyah in Bima regency selected through population techniques and 390 students through quota stratified random sampling. The data were collected by using questionnaires, test and documentation techniques.. The validity of the Instruments was done through logical. The questionnaire reliability was calculated by using Alpha Cronbach, while the questionnaires validity used content validity technique from expert and it was calculated by using Product Moment Corellation. Reliability coefficient of the questionnaires in terms of social studies instructional implementation process is 0.842 and learning outcome assessments and its follow-up is 0.772 . Based on test results, all the instruments are valid and reliable. The data are analyzed by using the quantitative descriptive analysis by comparing the results of this research with the predetermined criteria. Data analysis result shows that the implementation of the social studies instructional program for Junior High School/Madrasah Tsanawiyah in Bima regency with the education process standard, is as follows. (1) The instructional plan is in good (compatible)category. (2) The instructional process is in quite good (quite compatible) category. (3) The learning outcome assessments and its follow-up is in good (compatible) category. (4) students cognitive learning outcomes is in good (compatible) category with the learning minimal criteria standard.
\end{abstract}

Keywords:program evaluation, social studies instructional 


\section{Pendahuluan}

Inti dari pendidikan adalah pembelajaran sebagai proses interaksi manusiawi antara peserta didik (siswa) dengan pendidik (guru). Interaksi tersebut terjalin secara kompleks antar berbagai aspek dalam diri pribadi yang terlibat dalam proses pembelajaran. Dari sisi siswa, interaksi memberikan jaminan bahwa proses akan berjalan dan dapat menghasilkan keluaran (output) yang diharapkan, manakala siswa memiliki minat, motivasi, dan kemampuan untuk belajar. Teori belajar dan pembelajaran mengemukakan bahwa apabila siswa terlibat secara aktif dalam pembelajaran, maka output akan berkualitas. Teori pembelajaran inilah yang melahirkan pendekatan dan metode pembelajaran yang mengedepankan pada aktifitas siswa dalam belajar (student active learning).

Dari sisi guru, proses pembelajaran akan menjamin output yang berkualitas apabila guru menguasai materi, metode penyajian, menjalin hubungan yang akrab dengan siswa, serta kemampuan untuk menjadikan dirinya menarik bagi siswa. Dengan kemampuannya inilah, maka proses pembelajaran menjadi menarik, mencerdaskan, dan membangkitkan (joyfull).

Dalam Permendiknas Nomor 22 Tahun 2006 tentang Standar Isi disebutkan bahwa substansi mata pelajaran sosial di SD/MI, SMP/MTs, dan SMK dikemas dalam mata pelajaran IPS. Untuk menunaikan amanah tersebut, maka perlu dicarikan metode, teknik, serta cara pandang yang tepat untuk dapat memfasilitasi pelaksanaan pembelajaran yang sifatnya padu, agar dapat membantu peserta didik mencapai standar kompetensi yang ditentukan.

Saat ini mata pelajaran IPS SMP/MTs telah menyatukan seluruh kompetensi ilmu sosial dalam satu mata pelajaran.Model pembelajaran terpadu merupakan salah satu model implementasi kurikulum yang dianjurkan untuk diaplikasikan.Melalui pembelajaran terpadu, peserta didik dapat memperoleh pengalaman yang sesuai dengan kenyataan di masyarakat, sehingga dapat menambah kekuatan untuk menerima, menyimpan dan mereproduksi kesan-kesan tentang hal-hal yang dipelajarinya. Dengan demikian, peserta didik terlatih untuk dapat 
menemukan sendiri berbagai konsep yang dipelajari secara holistik, bermakna, otentik, dan aktif.

Berdasarkan Standar Proses Pendidikan dalam Peraturan Pemerintah Nomor 19 Tahun 2005 tentang Standar Nasional Pendidikan Pasal 19 Ayat (3) dan pasal 20 disebutkan bahwa:

Setiap satuan pendidikan melakukan perencanaan proses pembelajaran, pelaksanaan proses pembelajaran, penilaian hasil pembelajaran, dan pengawasan proses pembelajaran yang efektif dan efisien....Perencanaan proses pembelajaran meliputi silabus dan rencana pelaksanaan pembelajaran yang memuat sekurang-kurangnya tujuan pembelajaran, materi ajar, metode pengajaran, sumber belajar, dan penilaian hasil belajar.

Memahami amanah peraturan pemerintah tersebut, IPS sebagai bagian integral dari kurikulum sekolah, dinilai memerlukan guru-guru yang mampu melaksanakan pembelajaran secara efektif, dalam arti menguasai materi, mampu memilih permasalahan yang layak diangkat sebagai bahan belajar, serta mengembangkan strategi pembelajaran yang mampu mengoptimalkan pencapaian kompetensi. Melalui pembelajaran terpadu dalam IPS, siswa belajar memahami kenyataan hidup di masyarakat dengan berbagai ragam masalahnya yang tidak dapat dipecahkan menggunakan kata kerja keilmuan secara terpisah.Pembelajaran terpadu dinilai sebagai alternatif untuk menjawabnya.

Ada tiga model pengintegrasian materi dalam pembelajaran IPS yaitu: model integrasi berdasarkan topik, model integrasi berdasarkan potensi utama, dan model integrasi berdasarkan masalah. Selanjutnya, langkah yang harus dilakukan dalam merancang pembelajaran terpadu adalah pengembangan atau pemilihan tema-tema sebagai pemersatu. Tema dikembangkan berangkat dari cabang atau disiplin yang ada dalam IPS atau dari konsep umum mata pelajran IPS, kemudian disoroti dari berbagai disiplin lainnya, atau tema dikembangkan dengan melibatkan berbagai mata pelajaran (Panduan Pengembangan Pembelajaran IPS Terpadu SMP/MTs, Depdiknas: 2006). Hal terpenting dalam mengembangkan tema-tema ini adalah bahwa tema itu mampu menumbuhkan prinsip pembelajaran yang 
berpusat pada siswa (student centred) dan pembelajaran siswa aktif (student active learning).

Dalam sebuah program, pasti memiliki kelebihan dan kekurangan dalam pelaksanaannya. Oleh karena itu, penelitian ini dilakukan untuk dapat mengetahui kelemahan, kemudian dilakukan perbaikan dan penyempurnaan, sehingga diharapkan akan dapat meningkatan mutu pendidikan untuk masa mendatang. Banyak bukti yang menunjukkan bahwa sejumlah SMP/MTs tidak bisa melaksanakan kurikulum dengan baik. Hal ini dipengaruhi oleh beberapa aspek, yaitu perencanaan konsep kurikulum yang kurang sesuai dengan kondisi sekolah dan peserta didik, stakeholders sekolah yang tidak memahami metode pelaksanaannya, manajemen yang tidak profesional, serta keterbatasan kapabilitas (sumber daya manusia, perangkat lunak, perangkat keras, dan biaya).

Berdasarkan hasil wawancara dengan Kepala Seksi Kurikulum Pendidikan Menengah Kota Bima pada tanggal 23 September 2010, bahwa pelaksanaan pembelajaran IPS pada dua puluh enam SMP/MTs di Kota Bima, telah dimulai sejak tahun 2006/2007. Namun sampai saat ini, masih dijumpai adanya berbagai permasalahan yang terjadi di lapangan antara lain,guru kurang memahami konsep pembelajaran IPS yang padu, guru belum menyusunrencana pembelajaran IPS secara tepat, guru belum melaksanakan proses pembelajaran IPS secara padu, guru belum melaksanakan penilaian hasil belajar serta tindak lanjut hasil penilaian belajar IPS secara komprehensif, serta evaluasi terhadapprogram pembelajaran IPS SMP/MTs di Kota Bima belum pernah dilaksanakan, sehingga tidak diketahui tingkat kesesuaian antara pelaksanaan program pembelajaran IPS dengan standar proses pendidikan.

Berdasarkan latar belakang masalah, maka penelitian ini dibatasi pada permasalahan evaluasi terhadap program pembelajaran IPS SMP/MTs di Kota Bima yang belum pernah dilaksanakan, sehingga tidak diketahui tingkat kesesuaian antara pelaksanaan program pembelajaran IPS dengan standar proses pendidikan. Oleh karena itu, penelitian ini difokuskan pada evaluasi pelaksanaan program pembelajaran IPS SMP/MTs di Kota Bima, yang meliputi: perencanaan pembelajaran, pelaksanaan proses pembelajaran, dan penilaian hasil belajar dan tindak lanjut hasil penilaian. 
Hal ini juga dijadikan input berharga bagi para guru IPS, kepala sekolah, serta seluruh stakeholders pendidikan dalam upaya perbaikan dan pengembangan program pembelajaran IPS pada masa yang akan datang.

\section{Metode Penelitian}

Penelitian ini merupakan penelitian evaluasi dengan menggunakan Model Countenance Stake, yang meliputi evaluasi Antecedents, Transactions, dan Outputs (Worthen \& Sanders, 1973: 121). Berdasarkan model evaluasi Stake penelitian ini membandingkan kesesuaian antara pelaksanaan program pembelajaran IPS SMP/MTs di Kota Bima dengan standar proses pendidikan sebagai kriteria standar untuk menilai tingkat keberhasilan program IPS. Menurut Stake (Madaus, Schriven, \& Stufflebeam, 1986: 287308), Penekanan model ini adalah bahwa suatu evaluasi menekankan adanya pelaksanaan dua hal pokok, yaitu melakukan penggambaran (description) dan pertimbangan (judgement) mengenai sesuatu yang dievaluasi. Dengan demikian, tujuan pemilihan model evaluasi Countenance Stake dalam penelitian ini adalah untuk mengetahui kesesuaian antara pelaksanaan program pembelajaran IPS dengan standar proses pendidikan secara menyeluruh, yang meliputi perencanaan pembelajaran, pelaksanaan proses pembelajaran, penilaian hasil belajar dan tindak lanjut hasil penilaian, serta rerata hasil belajar kognitif IPS siswa pada 26 SMP/MTs di Kota Bima, tercantum pada tabel 1.

Berdasarkan tabel model evaluasi Stake program pembelajaran IPS SMP/MTs di atas, maka tahapan evaluasi dapat dijabarkan sebagai berikut:

1. Tahap perencanaan (Antecedents). Pada tahapan ini dilakukan evaluasi terkait kesesuaian antara perencanaan pembelajaran IPS SMP/MTs di Kota Bima dengan standar proses pendidikan.

2. Tahap pelaksanaan (Transactions). Pada tahapan ini dilakukan evaluasi terkait kesesuaian antara pelaksanaan proses pembelajaran IPS SMP/MTs di Kota Bima dengan standar proses pendidikan.

3. Tahap hasil (Outputs). Pada tahapan ini dilakukan evaluasi yang berfokus pada aspek outputs terkait kesesuaian antara penilaian hasil belajar dan tindak lanjut hasil penilaian belajar IPS SMP/MTs di Kota Bima dengan 
standar proses pendidikan, serta penilaian terhadap rerata hasil belajar IPS siswa pada $26 \mathrm{SMP} / \mathrm{MTs}$ di Kota Bima dengan standar Kriteria Ketuntasan Minimal belajar IPS SMP/MTs di Kota Bima.

Kesimpulan dari ketiga tahapan model evaluasi Stake tersebut adalah: (1) standar relatif (relative standard) yang menjelaskan pelaksanaan program pembelajaran IPS SMP/MTs di Kota Bima, dan (2) standar absolut (absolute standard), yakni mendasarkan pada standar atau kriteria standar proses pendidikan. Selanjutnya, dapat disimpulkan terkait kesesuaian antara pelaksanaan program pembelajaran IPS SMP/MTs di Kota Bima dengan standar proses pendidikan.

Tabel 1. Model Evaluasi Countenance Stake Program Pembelajaran IPS diSMP/MTs Kota Bima.

\begin{tabular}{|c|c|c|c|c|}
\hline No & & Description Matrix & & Judgement Matrix \\
\hline 1. & Antecedents & $\begin{array}{l}\text { Perencanaan } \\
\text { pembelajaran IPS } \\
\text { SMP/MTs di Kota } \\
\text { Bima }\end{array}$ & $\leftarrow$ Kesesuaian $\rightarrow$ & $\begin{array}{l}\text { Perencanaan } \\
\text { pembelajaran IPS } \\
\text { sesuai standar proses } \\
\text { pendidikan. }\end{array}$ \\
\hline 2. & Transactions & $\begin{array}{l}\text { Pelaksanaan Proses } \\
\text { pembelajaran IPS } \\
\text { SMP/MTs di Kota } \\
\text { Bima }\end{array}$ & $\leftarrow$ Kesesuaian $\rightarrow$ & $\begin{array}{l}\text { Pelaksanaan Proses } \\
\text { pembelajaran IPS } \\
\text { sesuai standar proses } \\
\text { pendidikan }\end{array}$ \\
\hline 3. & Outputs & $\begin{array}{l}\text { Penilaian hasil } \\
\text { belajar dan tindak } \\
\text { lanjut hasil penilaian } \\
\text { belajar IPS } \\
\text { SMP/MTs di Kota } \\
\text { Bima dan rerata } \\
\text { hasil belajar kognitif } \\
\text { IPS siswa }\end{array}$ & $\leftarrow$ Kesesuaian $\rightarrow$ & $\begin{array}{l}\text { Penilaian hasil belajar } \\
\text { dan tindak lanjut hasil } \\
\text { penilaian belajar IPS } \\
\text { sesuai standar proses } \\
\text { pendidikan dan KKM } \\
\text { Belajar IPS } \\
\text { SMP/MTS di Kota } \\
\text { Bima }\end{array}$ \\
\hline
\end{tabular}

266 - Jurnal Penelitian dan Evaluasi Pendidikan Tahun 16, Nomor 1, 2012 
Subjek penelitian adalah guru IPS sejumlah 78 orang yang diambil secara populasi dan siswa sejumlah 390 orang yang dipilih secara Quota Stratified Random Sampling. Teknik pengumpulan data yang digunakan adalah angket, tes, dan dokumentasi. Instrumen yang digunakan adalah kuesioner, tes, dan daftar cek. Untuk memperjelas deskripsi teknik pengumpulan data dalam evaluasi program pembelajaran IPS SMP/MTs di Kota Bima ini, maka dapat disajikan dalam tabel 2 sebagai berikut.

Tabel 2. Deskripsi Teknik Pengumpulan Data Evaluasi Program Pembelajaran IPS SMP/MTs di Kota Bima

\begin{tabular}{|c|c|c|c|l|}
\hline No & $\begin{array}{c}\text { Tahapan } \\
\text { Model } \\
\text { Evaluasi } \\
\text { Countenance } \\
\text { Stake }\end{array}$ & $\begin{array}{c}\text { Komponen } \\
\text { Evaluasi }\end{array}$ & $\begin{array}{c}\text { Teknik dan } \\
\text { Alat } \\
\text { Pengumpulan } \\
\text { Data }\end{array}$ & Sumber Data \\
\hline 1. & Antecedents & $\begin{array}{l}\text { Perencanaan } \\
\text { pembelajaran } \\
\text { IPS }\end{array}$ & $\begin{array}{l}\text { Dokumentasi } \\
\text { (Daftar Cek) }\end{array}$ & $\begin{array}{l}\text { Dokumen } \\
\text { Rencana } \\
\text { Pelaksanaan } \\
\text { Pembelajaran } \\
\text { (RPP) }\end{array}$ \\
\hline 2. & Transactions & $\begin{array}{l}\text { Pelaksanaan } \\
\text { Proses } \\
\text { pembelajaran } \\
\text { IPS }\end{array}$ & $\begin{array}{l}\text { Angket } \\
\text { (Kuesioner) }\end{array}$ & $\begin{array}{l}\text { Siswa Kelas VII, } \\
\text { VIII, IX }\end{array}$ \\
\hline 3. & Outputs & $\begin{array}{l}\text { Penilaian hasil } \\
\text { belajar dan } \\
\text { tindak lanjut } \\
\text { hasil penilaian } \\
\text { belajar IPS }\end{array}$ & $\begin{array}{l}\text { 1. Angket } \\
\text { (Kuesioner) }\end{array}$ & Tes \\
\hline
\end{tabular}

Validasi instrumen menggunakan validasi logis dari pertimbangan ahli dan validari empiris dengan menggunakan perhitungan Korelasi Product Moment. Sedangkan perhitungan reliabilitasinstrumen menggunakan rumus 
Alpha Cronbach. Koefisien reliabilitasangket pada aspek pelaksanaan proses pembelajaran IPS yaitu sebesar 0,842 dan penilaian hasil belajar dan tindak lanjut hasil penilaian sebesar 0,772 . Berdasarkan hasil uji coba, seluruh instrumen dinyatakan valid dan reliabel.

Penelitian ini menggunakan analisis data dengan teknik deskriptif kuantitatif yang bertujuan untuk memberikan gambaran realitas tentang pelaksanaan program pembelajaran IPS SMP/MTs di Kota Bima. Data dari hasil kuesioner, tes, dan daftar cek dianalisis secara deskriptif kuantitatif dengan cara membandingkan persentase perolehan skor pada tiap variabel yang diukur dengan kriteria penilaian yang telah ditentukan. Besarnya persentase dari hasil perhitungan menunjukkan kategori data yang terungkap, sehingga dapat diketahui posisi masing-masing variabel dalam keseluruhan maupun bagian dari variabel yang diteliti. Data dideskripsikan dengan mentabulasikan menurut masing-masing variabel. Berdasarkan perhitungan, maka diperoleh harga: mean, median, modus, skor minimum, dan skor maksimum.

Dalam mendeskripsikan aspek pelaksanaan program pembelajaran IPS, digunakan skor kriteria sebagai norma perbandingan yang digunakan sebagai kriteria perbandingan dalam menyusun kriteria empiris, yaitu kriteria yang disusun atau dikembangkan berdasarkan kondisi lapangan, yang diukur atau mengacu pada aspek program pembelajaran IPS, yang meliputi: perencanaan pembelajaran, pelaksanaan proses pembelajaran, penilaian hasil belajar dan tindak lanjut hasil penilaian belajar IPS, serta rerata hasil belajar kognitif siswa pada $26 \mathrm{SMP} / \mathrm{MT}$ s di Kota Bima. Adapun perhitungan kriteria data evaluasi yang diperoleh melalui teknik angket, tes, dan dokumentasi untuk masing-masing tahapan evaluasi dapat disajikan sebagai berikut:

\section{Evaluasi tahapan antecedents: Kriteria aspek perencanaan pembelajaran IPS}

Kriteria penilaian pada aspek perencanaan pembelajaran IPS ini diukur dari 20 butir pernyataan dengan pilihan jawaban menurut skala Likert dengan penskoran yang digunakan adalah skala 4, 3, 2, dan 1. Skor terendah yang diperoleh dari tiap-tiap respon adalah sebesar 20, sedangkan 
skor tertinggi adalah sebesar 80. Skor minimum dan maksimum dari datanya adalah sebesar 20 ( 1 x 20) sampai dengan 80 (4 x 20), sehingga luas jarak sebenarnya adalah $80-20=60$. Dengan demikian, Mean idealnya (Mi) sebesar 50, yakni $(1 / 2(80+20)$. Hasil perhitungan kriteria tersebut disajikan dalam tabel 3 sebagai berikut.

Tabel 3. Hasil Perhitungan Kriteria Perencanaan Pembelajaran IPS

\begin{tabular}{|c|c|}
\hline Interval Skor & Interpretasi/Kriteria \\
\hline $65-80$ & Sangat Baik/Sangat Sesuai \\
\hline $50-64$ & Baik/Sesuai \\
\hline $35-49$ & Cukup Baik/Cukup Sesuai \\
\hline $20-34$ & Kurang Baik/Kurang Sesuai \\
\hline
\end{tabular}

Berdasarkan acuan kriteria yang dijadikan patokan penilaian pada tabel 2 tersebut, maka skor yang berada pada rentang skor 20-34 dikelompokkan pada kategori kurang baik/kurang sesuai, berarti aspek perencanaan pembelajaran IPS yang dilakukan oleh guru dinilai kurang baik/kurang sesuai. Rentang skor 35-49 dikelompokkan pada kategori cukup baik/cukup sesuai. Rentang skor 50-64 dikelompokkan pada kategori baik/sesuai dan rentang skor 65-80 dikelompokkan pada kategori sangat baik/sangat sesuai.

\section{Evaluasi tahapan Transactions: Kriteria aspek pelaksanaan proses pembelajaran IPS}

Kriteria penilaian pada aspek pelaksanaan proses pembelajaran IPS ini diukur dari 42 butir pernyataan dengan pilihan jawaban menurut skala Likert dengan penskoran yang digunakan adalah skala 4, 3, 2, dan 1. Skor terendah yang diperoleh dari tiap-tiap respon adalah sebesar 42, sedangkan skor tertinggi adalah sebesar 168. Skor minimum dan maksimum dari datanya adalah sebesar 42 (1 x 42) sampai dengan 168 (4 x 42), sehingga luas jarak sebenarnya adalah $168-42=126$. Dengan demikian, Mean 
idealnya (Mi) sebesar 105, yakni (1/2 (168 + 42). Hasil perhitungan kriteria tersebut dapat dilihat pada tabel 4 sebagai berikut.

Tabel 4. Hasil Perhitungan Kriteria Pelaksanaan

Proses Pembelajaran IPS

\begin{tabular}{|c|c|}
\hline Interval Skor & Interpretasi/Kriteria \\
\hline $136,50-168$ & Sangat Baik/Sangat Sesuai \\
\hline $105-135,50$ & Baik/Sesuai \\
\hline $73,50-104$ & Cukup Baik/Cukup Sesuai \\
\hline $42-72,50$ & Kurang Baik/Kurang Sesuai \\
\hline
\end{tabular}

Berdasarkan acuan kriteria yang dijadikan patokan penilaian pada tabel 3 tersebut, maka skor yang berada pada rentang skor 42-72,5 dikelompokkan pada kategori kurang baik/kurang sesuai, berarti aspek proses pembelajaran IPS yang dilaksanakan oleh guru dinilai kurang baik/kurang sesuai. Rentang skor 73,5-104 dikelompokkan pada kategori cukup baik/cukup sesuai. Rentang skor 105-135,5 dikelompokkan pada kategori baik/sesuai dan rentang skor 136,5-168 dikelompokkan pada kategori sangat baik/sangat sesuai.

Evaluasi tahapan Outputs: Kriteria penilaian aspek penilaian hasil belajar dan tindak lanjut hasil penilaian, serta rerata hasil belajar kogntif siswa

Kriteria penilaian pada aspek penilaian hasil belajar dan tindak lanjut hasil penilaian belajar IPS ini diukur dari 24 butir pernyataan dengan pilihan jawaban menurut skala Likert dengan penskoran yang digunakan adalah skala 4, 3, 2, dan 1. Skor terendah yang diperoleh dari tiap-tiap respon adalah sebesar 24, sedangkan skor tertinggi adalah sebesar 96. Skor minimum dan maksimum dari datanya adalah sebesar 24 ( 1 x 24) sampai dengan 96 ( 4 x 24), sehingga luas jarak sebenarnya adalah $96-24=72$. 
Dengan demikian, Mean idealnya (Mi) sebesar 60, yakni $(1 / 2(96+24)$. Hasil perhitungan kriteria tersebut dapat dilihat pada tabel 5.

Tabel 5. Hasil Perhitungan Kriteria Penilaian Hasil Belajar dan Tindak Lanjut Hasil Penilaian Belajar IPS

\begin{tabular}{|c|c|}
\hline Interval Skor & Interpretasi/Kriteria \\
\hline $78-96$ & Sangat Baik/Sangat Sesuai \\
\hline $60-77$ & Baik/Sesuai \\
\hline $42-59$ & Cukup Baik/Cukup Sesuai \\
\hline $24-41$ & Kurang Baik/Kurang Sesuai \\
\hline
\end{tabular}

Berdasarkan acuan kriteria yang dijadikan patokan penilaian pada tabel 4 tersebut, maka skor yang berada pada rentang skor 24-41 dikelompokkan pada kategori kurang baik/kurang sesuai, berarti aspek penilaian hasil belajar serta tindak lanjut hasil penilaian belajar IPS yang dilakukan oleh guru dinilai kurang baik/kurang sesuai. Rentang skor 42-59 dikelompokkan pada kategori cukup baik/cukup sesuai. Rentang skor 6077 dikelompokkan pada kategori baik/sesuai dan rentang skor 78-96 dikelompokkan pada kategori sangat baik/sangat sesuai.

Adapun kriteria penilaian untuk mengukur outputs dari rata-rata hasil belajar kognitif IPS siswa pada 26 SMP/MTs di Kota Bima, diukur dari 25 butir soal jenis objektif pilihan ganda dengan pilihan 4 pilihan jawaban. Adapun teknik penskoran yang digunakan adalah skor 1 untuk jawaban yang benar dan skor 0 untuk jawaban yang tidak benar. Skor terendah yang diperoleh dari tiap-tiap respon adalah sebesar 1, sedangkan skor tertinggi adalah sebesar 25. Dengan demikian, Mean idealnya (Mi) sebesar 13. Hasil perhitungan kriteria tersebut dapat dilihat pada (tabel 5) sebagai berikut. 
Tabel 6. Hasil Perhitungan Kriteria ideal Penilaian Hasil belajar Kognitif IPS Siswa SMP/MTs

\begin{tabular}{|c|c|}
\hline Interval Skor Rerata & Interpretasi/Kriteria \\
\hline $19-25$ & Sangat Baik/Sangat Sesuai \\
\hline $13-18$ & Baik/Sesuai \\
\hline $7-12$ & Cukup Baik/Cukup Sesuai \\
\hline $1-6$ & Kurang Baik/Kurang Sesuai \\
\hline
\end{tabular}

Berdasarkan acuan kriteria yang dijadikan patokan penilaian pada tabel 5 tersebut, maka skor yang berada pada rentang skor 1-6 dikelompokkan pada kategori kurang baik/kurang sesuai. Rentang skor 712 dikelompokkan pada kategori cukup baik/cukup sesuai. Rentang skor 13-18 dikelompokkan pada kategori baik/sesuai dan rentang skor 19-25 dikelompokkan pada kategori sangat baik/sangat sesuai. Dari hasil perhitungan rerata skor hasil belajar kognitif IPS siswa pada tiap sekolah tersebut, selanjutnya dibandingkan dengan Kriteria Ketuntasan Minimal (KKM) skor pada mata pelajaran IPS SMP/MTs di Kota Bima, yakni sebesar 68.

Berdasarkan hasil analisis data dari berbagai instrumen di atas dapat dirangkum dan disimpulkan secara deskriptif kuantitatif menjadi data yang akurat untuk menjawab pertanyaan-pertanyaan penelitian terkait evaluasi program pembelajaran IPS SMP/MTs di Kota Bima.

\section{Hasil Penelitian dan Pembahasan}

\section{Deskripsi Data Hasil Penelitian}

Penelitian ini merupakan penelitian evaluasi dengan menggunakan Model Countenance Stake, yang meliputi evaluasi Antecedents, Transactions, dan Outputs dalam membandingkan kesesuaian antara pelaksanaan program pembelajaran IPS SMP/MTs di Kota Bima dengan standar proses pendidikan sebagai kriteria standar untuk menilai tingkat keberhasilan 
program IPS. Penekanan model ini adalah bahwa suatu evaluasi menekankan adanya pelaksanaan dua hal pokok, yaitu melakukan penggambaran (description) dan pertimbangan (judgement) mengenai sesuatu yang dievaluasi. Dengan demikian, tujuan pemilihan model evaluasi Countenance Stake dalam penelitian ini adalah untuk mengetahui kesesuaian antara pelaksanaan program pembelajaran IPS dengan standar proses pendidikan secara menyeluruh, yang meliputi perencanaan pembelajaran, pelaksanaan proses pembelajaran, penilaian hasil belajar dan tindak lanjut hasil penilaian, serta rerata hasil belajar kognitif IPS siswa pada 26 SMP/MTs di Kota Bima.

Pada bagian ini disajikan deskripsi data hasil penelitian dari masingmasing variabel dari objek penelitian program pembelajaran IPS SMP/MTs di Kota Bima. Deskripsi data yang disajikan meliputi rata-rata (mean), median, modus, standar deviasi, skor minimum, skor maksimum, dan distribusi frekuensi. Hasil perhitungan skor tersebut diperoleh dengan pengolahan data statistik berdasarkan program SPSS versi 17,0.

\section{a. Perencanaan Pembelajaran IPS SMP/MTs di Kota Bima}

Menurut Smith \& Ragan (Shambaugh \& Magliaro, 2006:35), perencanaan pembelajaran sebagai proses sistematis dalam menenjemahkan prinsip-prinsip belajar dan pembelajaran ke dalam rencana kegiatan dan bahan pembelajaran. Hal ini menunjukkan bahwa guru harus mempersiapkan perangkat yang harus disusun dalam merencanakan program pembelajaran. Hal tersebut menunjukkan bahwa perencanaan pembelajaran IPS memainkan peran penting dalam memandu guru untuk melaksanakan tugas sebagai pendidik dalam melayani kebutuhan belajar siswa.

Hasil analisis data membuktikan, kesesuaian antara perencanaan pembelajaran IPS SMP/MTs di Kota Bima dengan standar proses pendidikan berada pada kategori baik/sesuai. Kategori ini diperoleh berdasarkan analisa perhitungan skor rerata empiris data dari teknik dokumentasi Rencana Pelaksanaan Pembelajaran (RPP) yang dibuat oleh 78 orang guru IPS dari dua puluh enam SMP/MTs se-Kota Bima berdasarkan indikator-indikator variabel perencanaan pembelajaran, yakni 
sebesar 63,91, dengan persentase sebesar 66,7\%. Hasil penelitian ini menunjukkan bahwa guru telah menyusun RPP secara lengkap, tepat, dan penjelasan yang terperinci. Di samping itu, hasil penelitian ini juga menunjukkan bahwa 33,3\% perencanaan pembelajaran IPS SMP/MTs di Kota Bima termasuk dalam kategori sangat baik/sangat sesuai, namun tidak ada guru yang termasuk dalam kategori cukup baik/cukup sesuai dan kurang baik/kurang sesuai. Untuk menunjukkan persentase skor penilaian pada variabel perencanaan pembelajaran IPS tersebut dapat dilihat pada gambar 1 di bawah ini.

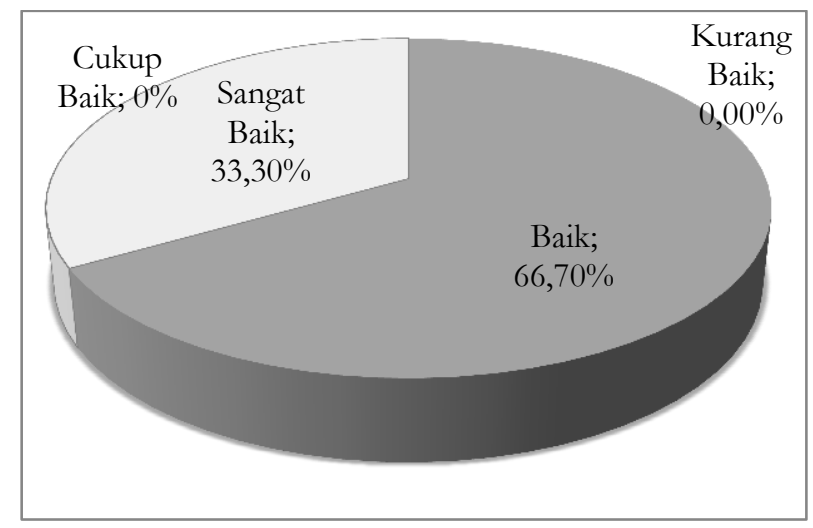

Gambar 1. Diagram LingkaranVariabelPerencanaanPembelajaran IPS

Berdasarkan diagram lingkaran, terdapat 33,3\% guru IPS SMP/MTs di Kota Bima menyusun perencanaan pembelajaran IPS dengan kategori baik/sesuai; 66,7 \% termasuk dalam kategori cukup baik/cukup sesuai dan tidak ada guru IPS SMP/MTs di Kota Bima yang termasuk dalam kategori kurang baik/kurang sesuai dan tidak baik/tidak sesuai.

\section{b. Pelaksanaan Proses Pembelajaran IPS SMP/MTs di Kota Bima}

Pelaksanaan proses pembelajaran menjadi sesuatu yang sangat penting dalam upaya mewujudkan output pendidikan yang berkualitas. Konsekuensinya, proses pembelajaran harus dilaksanakan secara tepat, 
ideal, dan proporsional sehingga guru harus memiliki kemampuan dalam melaksanakan teori pembelajaran ke dalam realitas pembelajaran yang kontekstual antara lain, mendesain, memfasilitasi, dan mengkondisikan situasi pembelajaran agar dapat dijadikan sarana untuk membimbing dan mengembangkan potensi siswa.

Pendekatan terpadu dalam mata pelajaran IPS lebih menekankan keterlibatan siswa dalam belajar, membuat siswa secara aktif terlibat dalam proses pembelajaran. Pendekatan pembelajaran terpadu dapat dipandang sebagai suatu upaya untuk memperbaiki kualitas pendidikan di tingkat dasar terutama dalam rangka penjejalan materi yang sering terjadi dalam pelaksanaan proses pembelajaran di sekolah dan lingkungan kehidupan sekitar siswa.

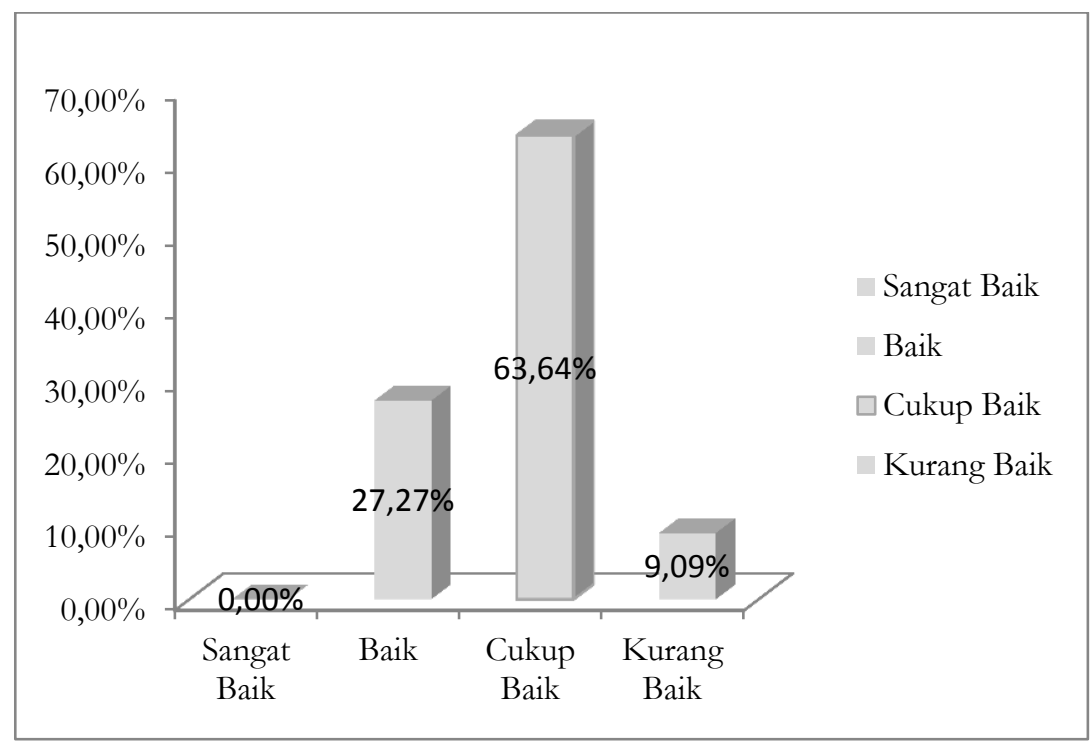

Gambar 2. Histogram Variabel Pelaksanaan Proses Pembelajaran IPS

Berdasarkan hasil analisis data, kesesuaian antara pelaksanaan proses pembelajaran IPS di Kota Bima dengan standar proses pendidikan berada pada kategori cukup baik/cukup sesuai. Kategori ini diperoleh berdasarkan 
analisa perhitungan skor rerata empiris dari teknik angket yang diberikan kepada 390 responden siswa dari dua puluh enam SMP/MTs se-Kota Bima berdasarkan indikator-indikator variabel proses pembelajaran IPS, yakni sebesar 104,75, dengan persentase sebesar 63,64\%. Hasil penelitian ini menunjukkan bahwa pelaksanaan proses pembelajaran IPS dilaksanakan secara bertahap, cukup sistematis, dan cukup menggunakan pembelajaran IPS yang padu. Untuk menunjukkan persentase skor penilaian pada variabel pelaksanaan proses pembelajaran IPS tersebut dapat dilihat pada (Gambar 3) di bawah ini.

Berdasarkan gambar di atas, dalam pelaksanaan proses pembelajaran tersebut terdapat $27,27 \%$ guru IPS yang termasuk dalam kategori baik/sesuai dan 9,09\% termasuk dalam kategori kurang baik/kurang sesuai. Namun tidak ada guru yang termasuk dalam kategori sangat baik/sangat sesuai dalam pelaksanaan proses pembelajaran IPS.

\section{c. Penilaian Hasil Belajar dan Tindak Lanjut Hasil Penilaian Belajar IPS SMP/MTs di Kota Bima.}

Evaluasi program pembelajaran IPS merupakan kegiatan untuk memperoleh, menganalisis, dan menafsirkan data tentang proses dan hasil belajar siswa yang dilakukan secara sistematis dan berkesinambungan sehingga menjadi informasi yang bermakna dalam pengambilan keputusan, memberikan umpan balik bagi siswa dalam mengetahui kemampuan dan kekurangannya dan akhirnya menimbulkan motivasi untuk memperbaiki hasil belajarnya.

Berdasarkan hasil analisis data, kesesuaian antara penilaian hasil belajar dan tindak lanjut hasil penilaian belajar IPS di Kota Bima dengan standar proses pendidikan termasuk dalam kategori cukup baik/cukup sesuai. Kategori ini diperoleh berdasarkan analisa perhitungan skor rerata empiris data dari teknik angket yang diberikan kepada 78 orang guru dari dua puluh enam SMP/MTs se-Kota Bima berdasarkan indikator-indikator variabel Penilaian hasil belajar dan tindak lanjut hasil penilaian belajar IPS, yakni sebesar70,94, dengan persentase sebesar 47,62\%. Hasil penilitian ini menunjukkan bahwa penilaian hasil belajar dan tindak lanjut hasil penilaian belajar IPS telah dilaksanakan oleh guru IPS SMP/MTs di Kota Bima 
secara bertahap dan komprehensif. Di samping itu, terdapat 28,57\% guru yang termasuk dalam kategori sangat baik/sangat sesuai; 19,05\% termasuk dalam kategori cukup baik/cukup sesuai; dan 4,76\% termasuk dalam kategori kurang baik/kurang sesuai.

Untuk menunjukkan persentase skor penilaian pada variabel penilaian hasil belajar dan tindak lanjut hasil penilaian belajar IPS tersebut dapat dilihat pada gambar 4.

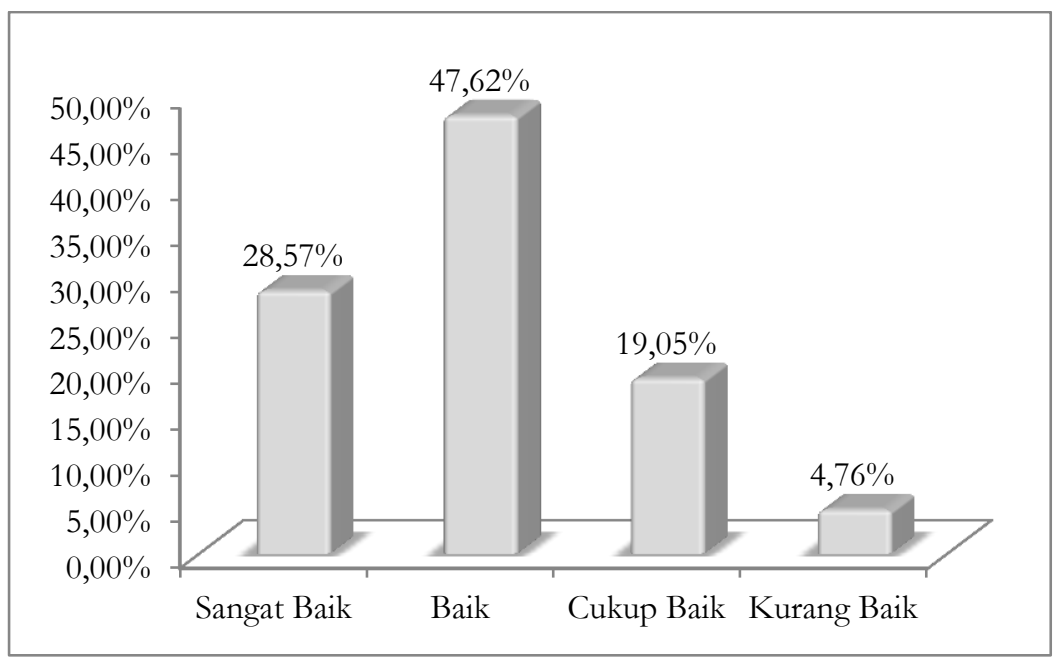

Gambar 3. Diagram Kerucut Variabel Penilaian Hasil Belajar dan Tindak Lanjut Hasil Penilaian Belajar IPS

Berpedoman pada kategori penilaian analisis data, rerata empiris variabel penilaian hasil belajar dan tindak lanjut hasil penilaian belajar IPS adalah sebesar 70,94 dan termasuk dalam kategori baik/sesuai.

\section{d. Hasil Belajar Kognitif IPS siswa SMP/MTs di Kota Bima}

Hasil belajar sebagai pencapaian kompetensi yang diperoleh siswa setelah mengikuti kegiatan belajar.Siswa yang berhasil dalam belajar adalah siswa yang berhasil mencapai tujuan-tujuan pembelajaran yang telah 
ditentukan.Tes digunakan untuk mengukur sejauh mana siswa telah menguasai materi yang telah disampaikan dalam pembelajaran.Tes merupakan himpunan pertanyaan yang harus dijawab, ditanggapi, atau berupa tugas yang harus dilaksanakan oleh orang yang dites.Berkaitan dengan hal tersebut, tes terhadap domain kognitif berupa kemampuan aspek pengetahuan siswa tentang materi pembelajaran.Dalam penelitian ini, penilaian hanya dibatasi pada evaluasi terhadap aspek kognitif IPS siswa SMP/MTs di Kota Bima.

Hasil analisis data hasil belajar kognitif IPS siswa pada 26 SMP/MTs di Kota Bima diperoleh rerata (mean) sebesar 81,05. Berpedoman pada kategorisasi interval rerata skor ideal yang telah ditentukan, maka rerata hasil analisis data hasil belajar kognitif IPS siswa berada pada kategori baik/sesuai berdasarkan standar Kriteria Ketuntasan Minimal (KKM) yang berlaku di Kota Bima. Untuk menunjukkan persentase perolehan skor rerata hasil belajar kognitif IPS siswa SMP/MTs di Kota Bima tersebut dapat dilihat pada (Gambar 5) sebagai berikut.

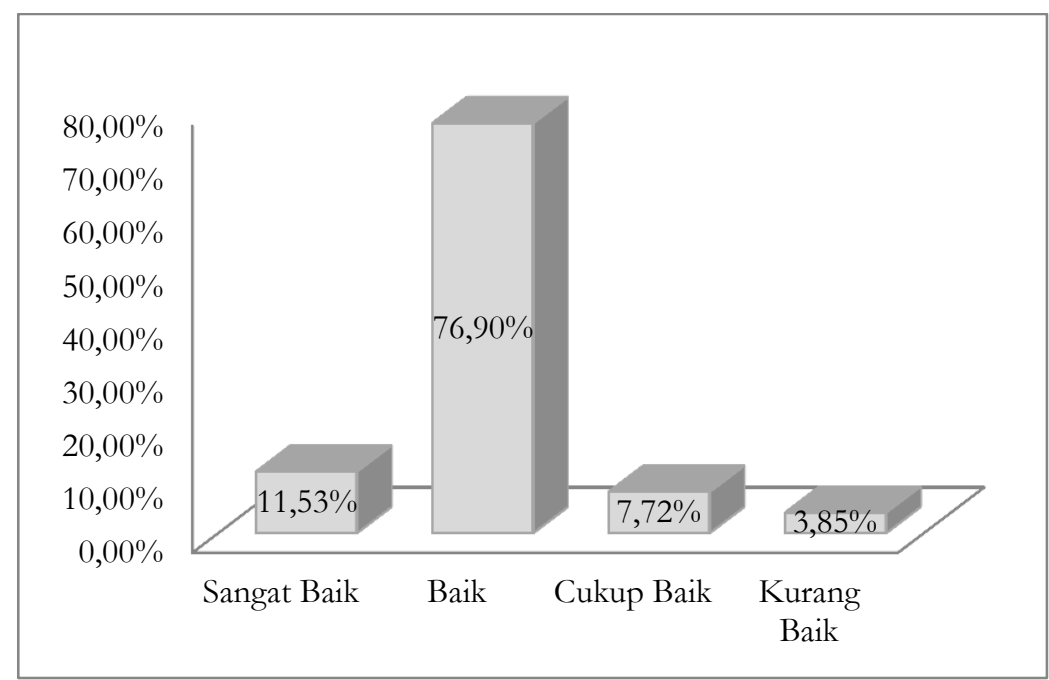

Gambar 4. Diagram Batang Perolehan Skor Rerata Hasil Belajar Kognitif IPS Siswa SMP/MTs di Kota Bima 
Berdasarkan gambar tersebut, secara umum perolehan skor rerata hasil belajar kognitif IPS siswa SMP/MTs di Kota Bima termasuk dalam kategori baik/sesuai dengan persentase sebesar 76,90\% dari 26 sekolah. Di samping itu, terdapat $11,53 \%$ sekolah yang termasuk dalam kategori sangat baik/sangat sesuai; 7,72\% termasuk dalam kategori cukup baik/cukup sesuai; dan 3,85\% termasuk dalam kategori kurang baik/kurang sesuai.

Hasil analisis data skor hasil belajar kognitif IPS siswa tersebut menunjukkan bahwa penilaian hasil belajar dan tindak lanjut hasil penilaian yang dilaksanakan oleh seluruh guru IPS SMP/MTs di Kota Bima telah sesuai standar proses pendidikan dan kondisi serta karakteristik peserta didik pada masing-masing satuan pendidikan.

\section{Simpulan}

Hasil analisis data menunjukkan bahwa kesesuaian antara pelaksanaan program pembelajaran IPS SMP/MTs di Kota Bima dapat disimpulkan sebagai berikut:

1. Perencanaan pembelajaran IPS SMP/MTs di Kota Bima berada pada kategori baik/sesuai dengan standar proses pendidikan. Hal tersebut menunjukkan bahwa perencanaan pembelajaran IPS SMP/MTs di Kota Bima disusun dengan lengkap, tepat, dan penjelasan yang terperinci.

2. Pelaksanaaan proses pembelajaran IPS SMP/MTs di Kota Bima berada pada kategori cukup baik/cukup sesuai dengan standar proses pendidikan. Hal tersebut menunjukkan bahwa proses pembelajaran IPS SMP/MTs di Kota Bima dilaksanakan secara bertahap, cukup sistematis dan menggunakan pendekatan pembelajaran IPS yang padu.

3. Penilaian hasil belajar dan tindak lanjut hasil penilaian belajar IPS SMP/MTs di Kota Bima berada pada kategori baik/sesuai dengan standar proses pendidikan. Hal tersebut menunjukkan bahwa penilaian hasil belajar dan tindak lanjut hasil penilaian belajar IPS dilaksanakan secara bertahap dan komprehensif.

4. Hasil belajar kognitif IPS siswa berada pada kategori baik/sesuai standar Kriteria Ketuntasan Minimum (KKM) belajar SMP/MTs di Kota Bima yang ditetapkan pada tahun ajaran 2010/2011. 
Berdasarkan hasil penelitian ini diharapkan dapat mengembangkan pembelajaran IPS sesuai KTSP yang berlandaskan pada standar proses pendidikan pada tingkat satuan pendidikan masing-masing melalui upaya pelatihan dan monitoring secara berkala dan berkesinambungan pada satuan pendidikan masing-masing melalui wadah Musyawarah Guru Mata Pelajaran (MGMP) IPS oleh pihak kepala sekolah maupun Dikpora Kota Bima selaku pengambil kebijakan pendidikan lokal.

Di samping itu, disarankan kepada pihak satuan pendidikan maupun Dikpora Kota Bima agar memberikan penghargaan bagi para guru IPS yang berprestasi dalam pelaksanaan program pembelajaran IPS, sehingga dapat memacu kreatifitas dan semangat diri untuk terus mengembangkan pembelajaran yang kreatif, aktif, menantang, inovatif, dan menyenangkan bagi para peserta didik.

\section{Daftar Pustaka}

Depdiknas. 2006. Panduan Pengembangan Pembelajaran IPS Terpadu $\mathrm{SMP} / \mathrm{MTs}$

Depdiknas. 2005.Peraturan Pemerintah RI Nomor 19, Tahun 2005, tentang Standar Nasional Pendidikan.

2006. Permendiknas RI Nomor 22, Tahun 2006, tentang Standar Isi.

Madaus, G. Scriven, M. \& Stufflebeam, L. Daniel. 1986. Evaluation models: Viewpoints on educational and human services evaluation. Boston: Kluwer-Nijhoff Publishing.

Shambaugh, N. \& Magliaro, G. Susan. 2006. Instructional design a systematic approach for reflective practice. United States of America: Pearson Education, Inc.

Worthen, R. \& Sanders, J. 1973. Educational evaluation theory and practice.California: Wardsworth Publishing Company. 